\title{
The Fish Fauna of Kuzgun Dam Lake and Its Drainages (Erzurum, Turkey)
}

\author{
Esra BAYÇELEBí ${ }^{1}$ Davut TURAN ${ }^{*}$ \\ ${ }^{1}$ Recep Tayyip Erdogan University, Faculty of Fisheries and Aquatic Sciences, 53100 Rize, Turkey
}

How to cite: Bayçelebi, E. \& Turan, D. (2020). The Fish Fauna of Kuzgun Dam Lake and Its Drainages (Erzurum, Turkey). J. Anatolian Env. and Anim. Sciences, 6(4), 522-525.

Atıf yapmak için: Bayçelebi, E. \& Turan, D. (2020). Kuzgun Baraj Gölü ve Drenajlarının Balık Faunası (Erzurum, Türkiye). Anadolu Çev. ve Hay. Dergisi, 6(4), 522-525.

* (DD : https://orcid.org/0000-0002-9586-6223

(iD) : https://orcid.org/0000-0001-6868-5091

\section{*Corresponding author's:}

Davut TURAN

Recep Tayyip Erdogan University, Faculty of

Fisheries and Aquatic Sciences, 53100 Rize,

Turkey

$凶:$ dvtturan@yahoo.com

\begin{abstract}
This study was carried out to determine the fish fauna of Kuzgun Dam Lake drainages. Fishes were caught by electro-fishing equipment, cast and gill nets. After anaesthesia, fish specimens were fixed in $4 \%$ formaldehyde and transferred to the laboratory for further identification. With this study eight species (Barbus lacerta, Capoeta damascina, Alburnus sellal, Alburnoides velioglui, Squalius semae, Oxynoemacheilus araxensis, O. bergianus and Salmo euphrataeus) belonging to four families (Cyprinidae, Leuciscidae, Nemachelidae and Salmonidae) were determined.
\end{abstract}

Keywords: Anatolia, euphrates river, ichthyofauna, taxonomy.

\section{Kuzgun Baraj Gölü ve Drenajlarının Balık Faunası (Erzurum, Türkiye)}

\section{*Sorumlu yazar:} Davut TURAN

Recep Tayyip Erdoğan Üniversitesi, Su Ürünleri Fakültesi, 53100 Rize, Turkey 凶:dvtturan@yahoo.com

\begin{abstract}
Öz: Bu çalışma Kuzgun Baraj Gölü ve drenajlarının balık faunasını belirlemek amacıyla yapılmıştır. Balık örnekleri elektroşok cihazı, serpme ve uzatma ağları ile toplanmış, anestezi yapıldıktan sonra balıklar \%4'lük formaldehit çözeltisinde fikse edilmiş ve tür tasnifleri için laboratuvara transfer edilmiştir. $\mathrm{Bu}$ çalışma ile 4 familyaya (Cyprinidae, Leuciscidae, Nemachelidae ve Salmonidae) ait sekiz tür (Barbus lacerta, Capoeta damascina, Alburnus sellal, Alburnoides velioglui, Squalius semae, Oxynoemacheilus araxensis, O. bergianus and Salmo euphrataeus) tespit edilmiştir.
\end{abstract}

Anahtar kelimeler: Anadolu, firat nehri, ihtiyofauna, taksonomi.

\section{INTRODUCTION}

The Euphrates River is the longest river in Southwest Asia. It is a transboundary river, which originates from eastern Anatolia, then through into Syria and then Iraq flows into the Persian Gulf Basin (Kaya et al., 2016). The main sources of the river are Murat River (originating from Ağr1-Diyadin) and Karasu River (originating from Erzurum-Dumludağ). These rivers merge within the borders of Elazı $\breve{g}$, then flows to the Euphrates River. The most important tributaries of the Euphrates in Turkey are Murat, Karasu, Tohma, Göksu, and Munzur rivers. A number of studies have been conducted on ichthyodiversity in the Euphrates River in Turkey. For example: Turan et al., (2014) revised the genus of Alburnoides and described three new species; Y1ldırım et al., (2015) studied on fishes in the Keban Dam Lake and recorded 28 species; Turan et al., (2017) described a new species (Squalius semae) of chub from the Karasu River; Koyun et al., (2018) revealed fish fauna of Göynük Stream and recorded 21 species; Freyhof et al., (2019) reviewed the Oxynoemacheilus Tigris group and described two new species from the Euphrates drainage; Kaya et al., (2020) described Paracobitis salihae from the Göksu River; Turan et al., (2021) described a new trout (Salmo fahrettini) from the Karasu River.

There are many dams on the Euphrates, one of them is Kuzgun Dam, which was built on the stream Sirl in Erzurum (eastern part of Turkey) between 1985-1996 for irrigation and energy generation. The present study aimed

${ }^{\left[{ }^{*}\right]}$ This study was produced from the master thesis. 
to determine the latest status of the fish fauna in the Kuzgun Dam Lake drainages.

\section{MATERIAL AND METHOD}

Fishes were caught by Samus 1000 pulsed DC electro-fishing equipment, cast and gill nets. After anaesthesia, fish specimens were fixed in $4 \%$ formaldehyde and transferred to the laboratory for further identification. We followed Kottelat and Freyhof, (2007) to identify species, Van der Laan et al., (2015) to arrange species in families. All species were arranged alphabetically within their own families. The species photos were shown in Figs 1-8. The global conservation status of the species is provided by International Union for Conservation of Nature (IUCN 2021).

\section{RESULTS}

A total of 8 fish species belonging to 4 families were recognized. The most species-rich family in the area is Leuciscidae (3 species), followed by Cyprinidae (2), Nemachelidae (2) and Salmonidae (1).

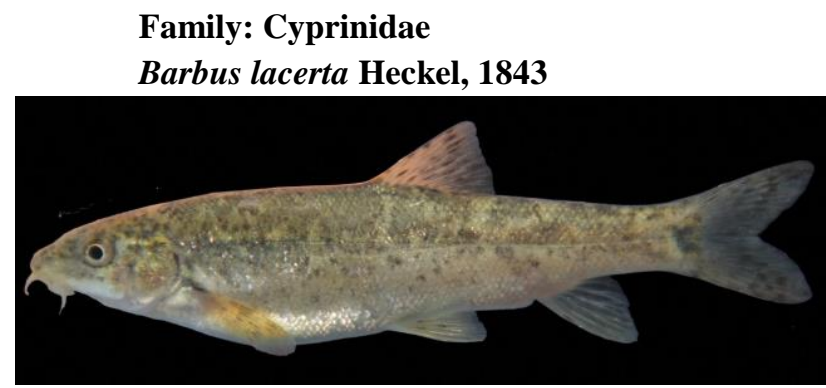

Figure 1. Barbus lacerta, Stream Sirlı

Locality: Sirl1 Stream.

Type locality: Qweik River near Aleppo, Syria.

IUCN status: Least concern (LC).

Endemism status: Non-endemic.

Distribution in the area: Euphrates and Tigris River drainages.

Capoeta damascina (Valenciennes, 1842)

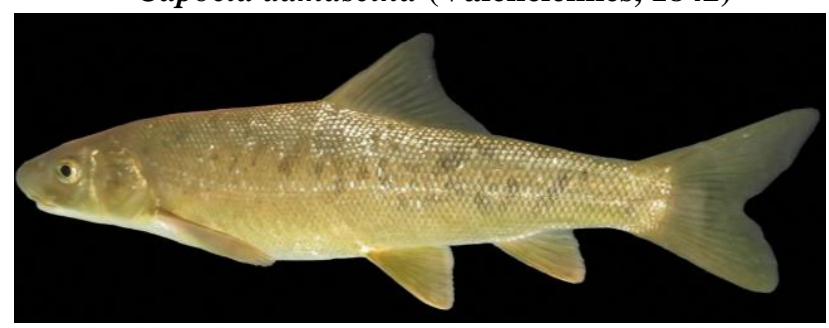

Figure 2. Capoeta damascina, Stream Sirlı.

Locality: Sırlı and Ağırcık streams.

Type locality: Damascus, Syria.

IUCN status: Least concern (LC).
Endemism status: Non-endemic.

Distributed area: Orontes, Qweik, Euphrates, Seyhan and Ceyhan River drainages. It also distributions in coastal streams Turkey to the Eastern Mediterranean (Alwan, 2010; Kaya et al., 2016, 2019; Bayçelebi, 2020).

Family: Leuciscidae

Alburnus sellal Heckel, 1843

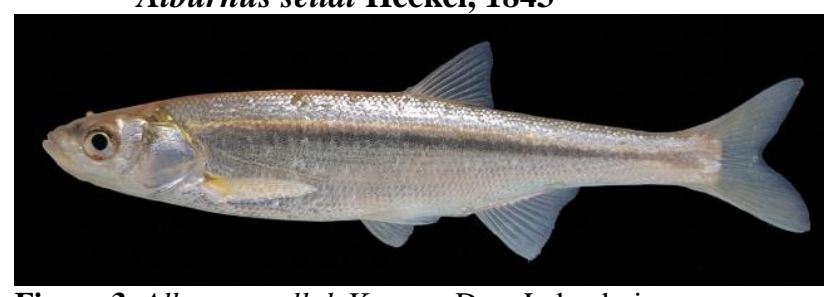

Figure 3. Alburnus sellal, Kuzgun Dam Lake drainage.

Locality: Kuzgun Dam Lake, Sırlı and Ağıcık streams.

Type locality: Qweik River, Aleppo, Syria.

IUCN status: Least concern (LC).

Endemism status: Non-endemic.

Distributed area: Euphrates, Tigris and Qweik River drainages (an uppermost drainage of Ceyhan River) (Bayçelebi, 2020).

Alburnoides velioglui Turan, Kaya, Ekmekçi \& Doğan, 2014

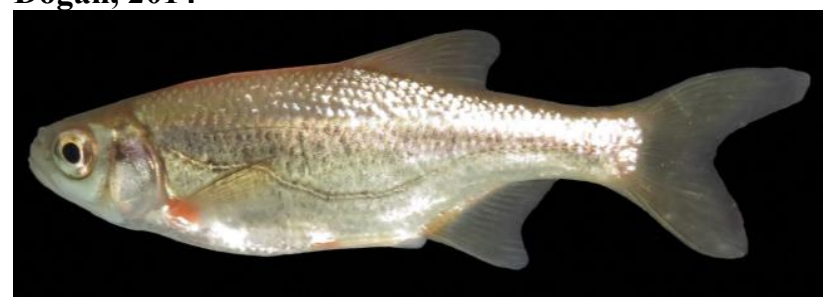

Figure 4. Alburnoides velioglui, Kuzgun Dam Lake Drainage.

Locality: Sirlı Stream.

Type locality: Stream Sirlı, Erzurum, Euphrates

River

IUCN status: Not Evaluated (NE).

Endemism status: Endemic.

Distributed area: Uppermost of Euphrates River drainage in Turkey (Turan et al., 2014).

Squalius semae Turan, Kottelat \& Bayçelebi,

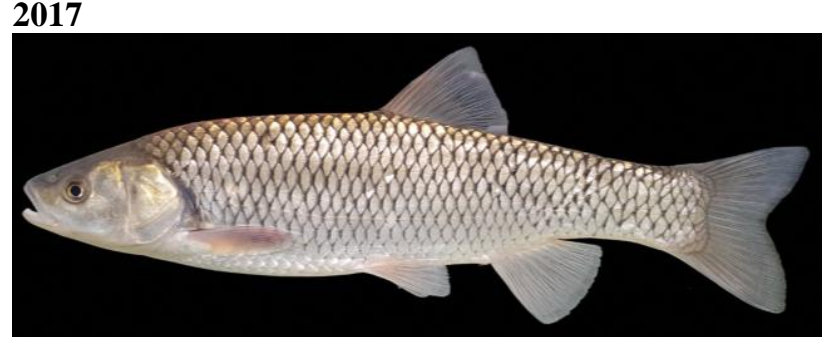

Figure 5. Squalius semae, Kuzgun Dam Lake Drainage.

Locality: Kuzgun Dam Lake and Sirlı Stream. 
Type locality: Stream Serçeme (Erzurum) Euphrates River.

IUCN status: Not Evaluated (NE).

Endemism status: Endemic.

Distributed area: Streams Sirl1, Toprakkale and Serçeme Pülümür and Murat River (northeastern drainage of Euphrates River) in Turkey (Turan et al., 2017).

Family: Nemachelidae

Oxynoemacheilus araxensis (Bănărescu \& Nalbant, 1978)

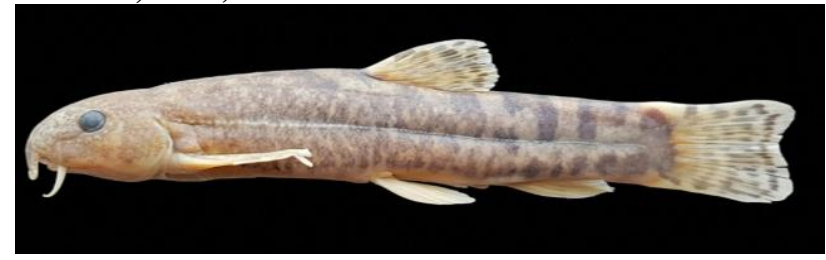

Figure 6. Oxynoemacheilus araxensis, Kuzgun Dam Lake Drainage.

Locality: Ağarcık Stream.

Type locality: Kandili Karasu, Euphrates River, Turkey.

IUCN status: Data Deficient (DD).

Endemism status: Endemic.

Distributed area: Stream Karasu, upper Euphrates River drainage.

Oxynoemacheilus bergianus (Derjavin, 1934)

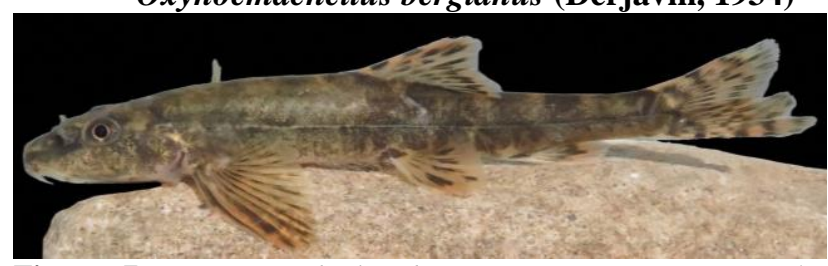

Figure 7. Oxynoemacheilus bergianus, Kuzgun Dam Lake Drainage.

Locality: Ağarcık Stream.

Type locality: Kisum village, Shah-rud River Iran

IUCN status: Least concern (LC).

Endemism status: Non-endemic.

Distributed area: Tigris and Euphrates River drainages, as well as in Caspian Sea basin (Freyhof et al. 2019)

\section{4}

Family: Salmonidae

Salmo euphrataeus Turan, Kottelat \& Engin,

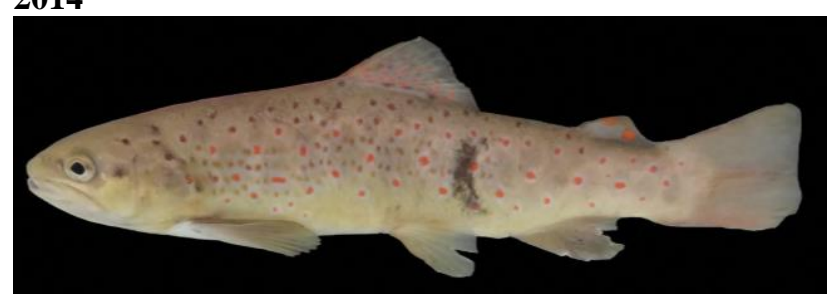

Figure 8. Salmo euphrataeus, Kuzgun Dam Lake Drainage.
Locality: Sırlı and Ağarcık streams.

Type locality: Stream Kuzgun (Erzurum) Euphrates River drainage.

IUCN status: Not Evaluated (NE).

Endemism status: Endemic. dranaige.

Distributed area: Upper Euphrates River

\section{DISCUSSION AND CONCLUSION}

A total of eight fish species were identified from the Kuzgun Dam Lake and its drainages. Among these species, Salmo euphrataeus, Alburnoides velioglui and Oxynoemacheilus araxensis were first described from this reservoir and its drainages. In this respect, the fish fauna of this dam lake and its drainages are important for aquatic biodiversity. It is recommended by us that the fish fauna of these dams and their drainage should be strictly protected at the ecosystem level. As a result, this study revealed the latest status of the fish fauna in the Kuzgun Dam Lake drainages.

\section{ACKNOWLEDGEMENTS}

We thank Cüneyt Kaya (Rize) for field studies.

\section{REFERENCES}

Alwan, N., Esmaeili, H.R. \& Krupp, F. (2016). Molecular phylogeny and zoogeography of the Capoeta damascina species complex (Pisces: Teleostei:Cyprinidae). Plos One, 11, 1-25.

Freyhof, J., Kaya, C., Turan, D. \& Geiger, M. (2019). Review of the Oxynoemacheilus tigris group with the description of two new species from the Euphrates drainage (Teleostei: Nemacheilidae). Zootaxa, 4612(1), 29-57.

IUCN [International Union for the Conservation of Nature] (2021). IUCN Red List of threatened species. Version 2014.3. http://www. iucnredlist.org [August 2021]

Kaya, C., Turan, D. \& Ünlü, E. (2016). The latest status and distribution of fishes in upper tigris river and two new records for Turkish freshwaters. Turkish Journal of Fisheries And Aquatic Sciences, 16, 545-562.

Kaya, C. (2019). Taxonomic revision of the species belong to genus Capoeta distributed in Turkey. PhD Thesis. Recep Tayyip Erdogan University, Institute of Science and Technology, Rize, Turkey, 126 pp.

Kaya, C., Turan, D., Kalaycı, G., Bayçelebi, E. \& Freyhof, J. (2020). The westernmost known population of Paracobitis (Teleostei, Nemacheilidae), with the description of a new species from the Euphrates River in southern Anatolia. Zootaxa, 4838(4), 525-534. 
Kottelat, M. \& Freyhof, J. (2007). Handbook of European Freshwater Fishes. Kottelat, Cornol, Switzerland and Freyhof, Berlin, 646 pp.

Koyun, M., Gül, B. \& Korkut, N. (2018). Göynük çayı (Bingöl) balık faunası. Commagene Journal of Biology, 2(1), 39-47.

Turan, D., Kaya, C. Ekmekçi, F.G. \& Doğan, E. (2014). Three new species of Alburnoides (Teleostei: Cyprinidae) from Euphrates River, Eastern Anatolia, Turkey. Zootaxa, 3754(2), 101-116.

Turan, D., Kottelat, M. \& Bayçelebi, E. (2017). Squalius semae, a new species of chub from the Euphrates River, Eastern Anatolia (Teleostei: Cyprinidae). Zoology in the Middle East, 63(1), 33-42.

Turan, D., Kalaycı, G., Bektaş, Y., Kaya, C., Bayçelebi, E. (2020). A new species of trout from the northern drainages of Euphrates River, Turkey (Salmoniformes: Salmonidae). Journal of Fish Biology, 96(6), 1291-1545.

Van der Laan, R. (2017). Freshwater Fish List. 23rd edition, ISSN: 2468-9157, Almere, The Netherlands, 997 pp.

Yıldırım, T., Şen, D., Eroğlu, M., Çoban, M., Demirol, F., Gündüz, F . Arca, S., Demir, T., Gürçay, S., Uslu, A. \& Canpolat, İ . (2015). Keban baraj gölü balık faunası, Elazı̆̆g, Türkiye. Fırat Üniversitesi Fen Bilimleri Dergisi, 27(1), 57-69. 